\title{
Determinants of Academic Library Service Quality across Sri Lanka: A Marketing Perspective
}

\author{
K. R. N. Harshani ${ }^{1}$, Zafar U. Ahmed ${ }^{2}$, Ali Khatibi ${ }^{3}$ \\ ${ }^{1}$ Ph.D., Candidate, Department of Marketing, College of Business Administration, Management and Science University, Malaysia \\ ${ }^{2}$ Professor of Marketing, Department of Marketing, School of Business, American University of Ras Al Khaimah, \\ Ras Al Khaimah, United Arab Emirates \\ ${ }^{3}$ Professor of Marketing, Vice President for Business and Social Sciences, Director: Graduate School of Management \\ Management and Science University, Kuala Lumpur, Malaysia
}

\begin{abstract}
Libraries as depository of knowledge have been the backbone of academic institutions since the dawn of civilization. They contribute immensely to the development and dissemination of new research, educational learning experience of their clients and by serving their community in numerous ways and means. The service quality of a library is affected by the user experiences and about their assessment of library environment, facilities and assess to wide range of information resources, databases, technological orientation, staff attitudes, size of collection and other related matters. Contemporary libraries need to change their products and services with the passage of time, advancement in technology and globalization of library environment(s). This research study attempts to develop a theoretical model to examine and assess consumer satisfaction within a library setting from a small island nation and emerging country (Sri Lanka) perspective.
\end{abstract}

Keywords: SERVQUAL, service quality, academic library, library marketing, customer, satisfaction, quality management, higher education, services marketing, library service, Sri Lanka.

\section{Introduction}

Academic libraries are backbone of higher education institutions. In addition to providing assistance for research, educational learning and promotion of services to its academic community, libraries need to upgrade university research and innovative work capacities in order to meet the growing global expectations of knowledge.There is a requirement for service providers to provide their services reliably and quantifiable manner. The execution of educational facilities at libraries needs to be upgraded from the students' viewpoint at universities. This is because of the fact that the students are identified as the directly the primary customer from the marketing viewpoint. Identification of the procedure of library service delivery is consequently is essential to test their sentiments on the quality of services as well as the quality of education (Oluwunmi, et al. 2016). That is undoubtedly accepted that customer satisfaction is a key element of any association including academic institutions like university libraries. University library traditional setting and some aspects of the services has been changeddue to the emergence of various information providers such as vendors, internet, Amazon and Google.

Khan and Kamal (2016) stated that libraries assume akeypart to market their information services for the advantageof their users to use new technologies and to anticipate the trends.Libraries and information centers have ended up benefiting organizations because of new technological storage, processing, retrieval \& services.Calculation of library service quality supports in finding shortcoming and quality parts alongside with diminishing the gap between customers' perceptions and desires (Rehman, 2012). It is vital for service providers to frequently measure the performance of educational facilities' service quality especially library services for consistent improvement from the students' point of view. Chen (2016) noted that, most fundamental part of an academic library is to give correct, generous and powerful service to users. Furthermore, it is called as heart of a university. With the increasingly drastic race among extensive variety of data services and expanded society necessities, libraries must highlight service quality in order to drawin an everincreasing number of clients and upgrade viable library administrations.

However, the services of a library areinfluenced by user experiences and perceptions. For example, their evaluation of the environments, facilities, access to wide range of information resources, staff attitudes, size of collections and related reading exercises affect the library service delivery significantly.In order to increase the user satisfaction and library service quality, it has to have an effective and efficient library service.(Mohindra and Kumar 2015). Moreover, considering the high level of service quality is rapid for the triumph of library framework, thequality of library services have to be enhanced. Moses et.al. (2016) additionally includedthat fact that service quality assessment is done by differentresearchers proposed by diverse models such as,webQUAL, siteQual, E-S-Qual, DigiQULA, LibQual, Servqual, and so forth.Rapid technological advancement in information technologies has created changes in library service delivery process, reclassifieddata gathering, and have made a request on library staff aptitudes, library facilities and infrastructure.

Edveor (2016) states that marketing underpins a library staff's capability encourage an association's main goal, advance profitability by rapidly and effectively finding the correct data at the perfect time. It encourages joint effort between individuals or organizations, technology, methods and information sources.In libraries, marketing is essential

\section{Volume 6 Issue 12, December 2017}




\section{International Journal of Science and Research (IJSR) \\ ISSN (Online): 2319-7064}

Index Copernicus Value (2016): 79.57 | Impact Factor (2015): 6.391

for expandingcollaborations between the users and the library. This will help achievethe organizations' central goal delivering best quality information and provide knowledge to the society at large while expanding the net benefit.Libraries are developing associations where assets and labor are expanding gradually. Therefore, it needs new methodologies advanced instruments. They need to advance library administrations among the customers and also their organizational improvement (Milan and Kamal 2016).

Basically, it is expected that librarians have fulfilled the clients' aim of build up the picture of their libraries. For example, libraries must be an exemplary model in terms of permission and administrations they give. Marketing of library administrations executes every one of the exercises of library and it has expanded the goal of client's fulfillment(Jessy and Rao 2016). Marketing of libraries is fundamental for various reasons. Those could be such as offering learning aids to clients' requirement diminish boundaries to utilize the libraries and empower and illuminate the clients in the administrations when the services offered by libraries (Gupta, 2016). Today, library needs to provide high quality services so as to attract student and increase institutional improvements. Clients of the library additionally expect and acknowledge just quality items and administrations. In this setting administration quality is one of the essential targets of college library framework. The realities of the current library circumstance show that new promotional and marketing efforts are fundamental to ensure the fulfillment of users' needs and in supporting teaching, learning and research culture.An academic library operates in a rapidly evolving setting.It is supervised and managed by a librarian, who is identified as one of the key officers of a University. That is further assisted by a panel of experts, professionals and supporting staff. The mission of the academic libraries is to create a favorable environment for learning, education and research by providing an assortment of capabilities such as the preparation course books, supplementary reference and reading materials, periodicals, and recreational assets (Velnamby and Sivesan 2013).

\section{Literature Review}

\section{SERVQUAL}

Service quality evaluation first originated from business and retailing organizations. However with the social and economic changes evoked the libraries to develop its service quality. Library is a service organization and it is main objective is to make available proper documents, information and services to its customers. The staff of the library has an important role in satisfying its users.

In this global era quality measurement and evaluation presumes utmost importance in present libraries as it brings enormous advantages to library itself as well as the society.Libraries quality evaluation is important to know where they stand, the place they ought to be, what actions should take to develop it to a higher level and finally to know whether library has catered to users expectations successfully to make them satisfied with the service.
In the bright of client's discernments and cravings, custodians can improve library administrations and overhaul their administration arrangements. It was at first created by Parasuraman et al (1988).It is an evaluation of service quality of institutions. There are 22 item tool which is reflected in their perceived and desired service levels alongside 7 point likert scale. The 22 scale explanations of instrument under five attributes are presented in Figure 1.1

\begin{tabular}{|c|c|}
\hline \multicolumn{2}{|c|}{ Five Dimensions of service quality defined } \\
\hline Dimensions & $\begin{array}{c}\text { Definitions } \\
\text { The capacity to play out the assured } \\
\text { advantage constantly and precisely }\end{array}$ \\
\hline Responsiveness & $\begin{array}{c}\text { The willingness to help clients and give incite } \\
\text { service. }\end{array}$ \\
\hline Assurance & $\begin{array}{c}\text { The knowledge and courtesy of employees } \\
\text { and their capacity to pass trust and certainty }\end{array}$ \\
\hline Empathy & $\begin{array}{c}\text { The caring individualized consideration given } \\
\text { to customers }\end{array}$ \\
\hline Tangibles & $\begin{array}{c}\text { The exterior of physical facilities, equipment, } \\
\text { personnel, and communication resources }\end{array}$ \\
\hline
\end{tabular}

Figure 1: Five Dimensions of service quality defined (Source: Fitzsimmons, J. A., Fitzsimmons, M. J., \&Bordoloi, S. 2006)

\section{Service Quality In Academic Library}

LibQUAL was produced in to an instrument for library service quality assessment by the Association of Research Libraries (ARL) in the United States of America in October 1999. The areas of the device are as per the following:

- Affect of Service: It consolidates three types of the administration spaces distinguished by SERVQUAL into one. Those areas are confirmation, compassion, and unwavering quality;

- Reliability: Capability to play out the guaranteed benefit constantly and precisely;

- Access to Information: Entree is guaranteed via the arrangement of far reaching accumulations and omnipresence of get to, or the arrangement through all methods conceivable of hindrance open entrance to data when required;

- Library as Place: Capability to meet group necessities and give place to study, cooperation, or meet;

- Self-dependence: Capability that cultivate independent, data looking for conduct through direction, coaching, signage and different means (Cook, Heath and Thompson 2001).

\section{Marketing Concepts in the Library Context}

Libraries are in the center of providing source of information and similar resources to its customer base. Accordingly the libraries core activity resides in the intangible services like encouraging its user to access information and they try to impact the utilization of tits users by different ways such as librarians wearing smiles on their faces will encourage customers to borrow books and to refer books.Today, a library is generally viewed as destination for information market and the library readers are identified as consumers of information. Information is an important asset for research and development of any country. Marketing is fundamental in creating the right arranging, outlining and usage of such 


\section{International Journal of Science and Research (IJSR) \\ ISSN (Online): 2319-7064 \\ Index Copernicus Value (2016): 79.57 | Impact Factor (2015): 6.391}

kind of services and products for the enhancement and best use of information.

In this information age, the library is concerned as a destination from where the users obtain endless opportunities for new learning and sharing new knowledge. The process of providing the service has to be upgraded to match the users' expectation. The traditional definition of library has to be changed under the marketing contexts. Under the philosophy of marketing, a library needs to be responsive to its users, develop relationship with the users, should have distinction of the service delivery and should meet the expectations of the users in every aspect with respect to the services provided in a library.Marketing is an essential capacity in libraries and information centers focuses to keep themselves in steady touch with the customers, to comprehend their requirements, to create items and administrations that address these needs lastly, to develop a general channel of communication.

The decision before librarians and information centers is not whether to market their items or services since none of them can abstain marketing, in the event that they need to wind up distinctly self-supporting in the long run, yet to do it well. Henceforth the requirements for academic librarians are to market library services to users. Academic librarians have been charged with the description of record (ordering and abstracting), their substance, components and reason including the association of such report. Ordering and abstracting is a method for such description to give access to their recognizable and retrieval.
Marketing indexing and abstracting services by academic libraries will improve client's awareness on the best way to find materials in the subject area of knowledge they require and also giving summaries of the substance of reading materials in the library along these lines filling in as help for library users. Madhusudhan (2008) recorded the advantages of showcasing data by college libraries to include:

1) Advancement of the usage of information resources.

2) Generate perception of requirement and thereby produce request.

3) Guarantee the optimal use of information.

4) Increase the appearance and position of the library profession and libraries.

5) Challenge the problems of increasing expenses of reading materials, journals and databases.

6) Manage with the information exploding.

7) Reveal cutting control information technology systems in library services.

8) Balance decrease moneys.

9) Save libraries from devaluation.

Marketing is guarantee securing of resource for utilization. Make item accessible in a reasonable area saving the season of reader either by decentralization of informationor by digitizing the information.

\section{Conceptual Framework}

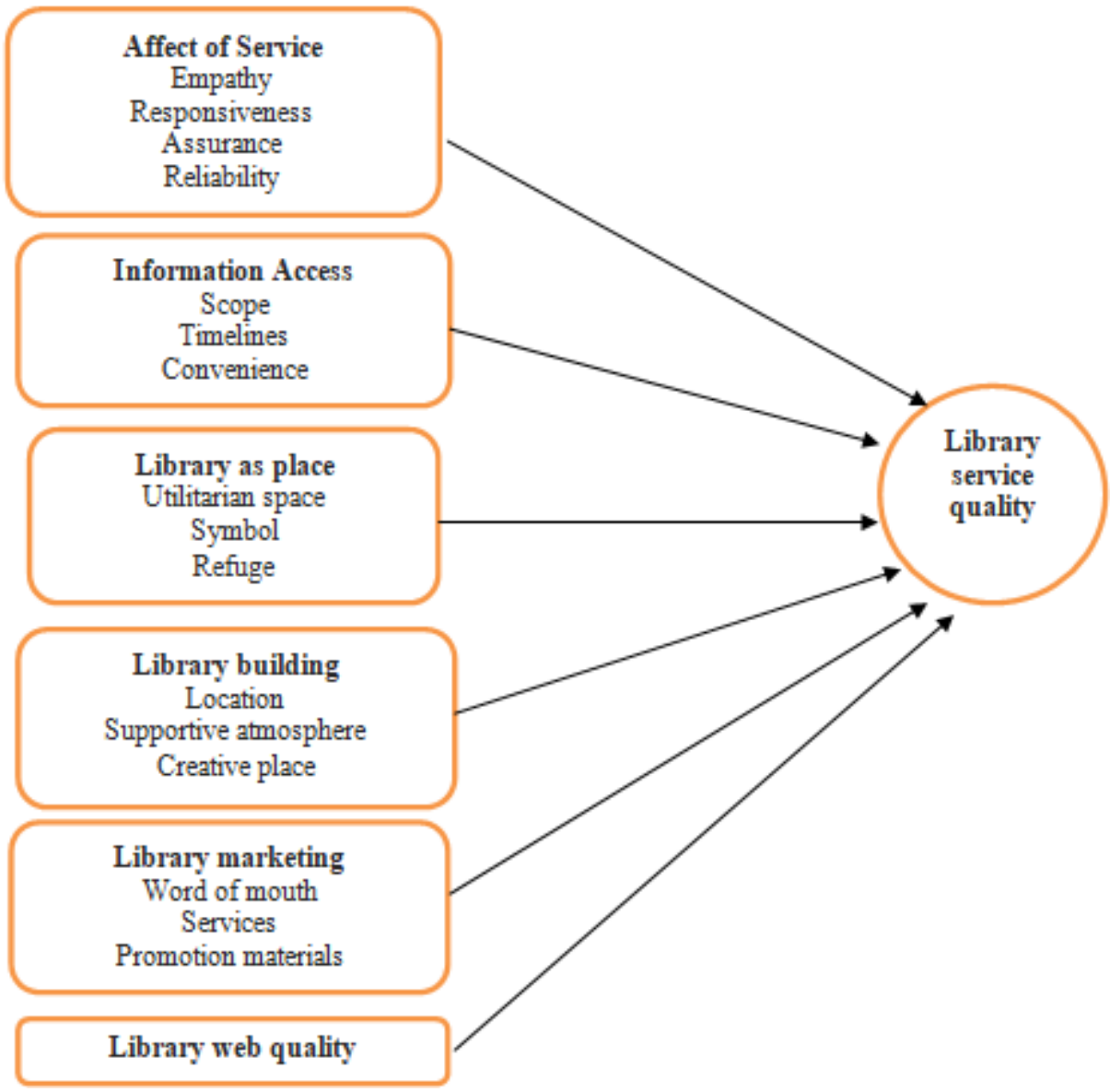

Figure 2: Conceptual Framework

(Source: Authors' unique creation originated on previous literature review)

Volume 6 Issue 12, December 2017 www.ijsr.net

Licensed Under Creative Commons Attribution CC BY 


\section{International Journal of Science and Research (IJSR) \\ ISSN (Online): 2319-7064 \\ Index Copernicus Value (2016): 79.57 | Impact Factor (2015): 6.391}

\section{Figure 3: List of Hypotheses}

\section{List of Hypotheses}

H1: The affect of service increases library service quality

$\mathrm{H} 2$ : The information access increases library service quality

H3: The library as a place increases library service quality

H4: The library building increases library service quality

H5: The library marketing increases library service quality

H6: The empathy increases the library service quality

$\mathrm{H} 7$ : The responsiveness increases the library service quality

H8: The assurance the library service quality

H9: The reliability the library service quality

H10: The scope the library service quality

H11: The timelines the library service quality

H12: The convenience increases the library service quality

H13: The utilization space increases the library service quality

H14: The symbol increases the library service quality

H15: The refuge increases the library service quality

H16: The location increases the library service quality

H18: The supportive atmosphere increases the library service quality

H19: The creative place increases the library service quality

H20: The word of mouth increases the library service quality

H21: The services increases the library service quality

H22: The quality increases the library service quality

H23: The library web quality increases the library service quality

\section{Excepted Benefits of the Research}

Discoveries of this review will bring a few advantages to decision makers, library users and furthermore to the workers in the field of academic libraries in Sri Lanka. This research will give a few commitments to basic leadership forms in academic library of comparative nature as far as Sri Lanka is concerned. Specialists in this field can utilize the model and the discoveries in their future research work. This information is critical to the librarians who are responsible of managing the exercises of their workers.

They can utilize the findings of the study in dealing with the execution of their staff. Facilitate the data from the review will be utilized to recognize the zones for program arranging identifying with administration change and aggregate administration quality in academic library, from the clients perspective. The review helps in distinguishing determinants of library user fulfillment. As specified, decision makers can utilize the information and investigation to survey the adequacy of the current administrations frame the user's perspective.

\section{References}

[1] Ali, S. Y. A., \& Mohammed, I. A. (2014).Service quality provided by higher education institutions in Somalia and its impact on student satisfaction. European Journal of Business and Management, 6(11), 143-48.

[2] Chen, Y. T. (2016). Applying the DEMATEL approach to identify the focus of library service quality: a case study of a Taiwanese academic library. The Electronic Library, 34(2), 315-331.
[3] Cheney, K. (2007) Marketing law libraries: strategies and techniques in the digital age.Legal Reference Services Quarterly, 26(1/2), pp. 281-299.

[4] Cook, C., \& Heath, F. M. (2001). Users' perceptions of library service quality: A LibQUAL+ qualitative study. Library Trends, 49(4), 548.

[5] Dahan, S. M., Taib, M. Y., Zainudin, N. M., \& Ismail, F. (2016).Surveying Users' Perception of Academic Library Services Quality: A Case Study in Universiti Malaysia Pahang (UMP) Library. The Journal of Academic Librarianship, 42(1), 38-43.

[6] Edewor, N., Okite-Amughoro, F., Osuchukwu, N. P., \&Egreajena, D. E. (2016).Marketing library and information services in selected university libraries in Africa. International Journal of Advanced Library and Information Science, 4, pp-291.

[7] Fitzsimmons, J. A., Fitzsimmons, M. J., \&Bordoloi, S. (2006). Service management: Operations, strategy, and information technology. New York: McGraw-Hill.

[8] Gupta, D. K. (2016). Everything is Marketing: An Analysis of Functional Relationships of Marketing and Libraries. DESIDOC Journal of Library \& Information Technology, 36(3).

[9] Halim, S., Wulandari, D., \&Kasih, D. (2016). Digital natives: Its characteristics and challenge to the library service quality. In Proceedings of Second International Conference on Electrical Systems, Technology and Information 2015 (ICESTI 2015) (pp. 487-494).Springer Singapore.

[10] Jayasundara, C., Ngulube, P., \&Minishi-Majanja, M. K. (2009).A theoretical model to predict customer satisfaction in relation to service quality in selected university libraries in Sri Lanka. South African Journal of Libraries and Information Science, 75(2), 179-194.

[11] Jessy, A., \&Rao, M. (2016). Marketing of resources and services with emerging technologies in modern libraries: An overview. International Journal of Information Dissemination and Technology, 6(1), 15.

[12] Johnson, K. (2016). Understanding and Embracing Service Design Principles in Creating Effective Library Spaces and Services.In The Future of Library Space (pp. 79-102). Emerald Group Publishing Limited.

[13] Kettinger, W. J., \& Lee, C. C. (1994). Perceived service quality and user satisfaction with the information services function. Decision sciences, 25(5-6), 737-766.

[14] Khan. M. Milan and Kamal, Mostafa. (2016). Marketing of Library and Information Services in University Libraries: A Practical Experience. Asian Journal of Multidisciplinary Studies. Vol.4, Issue 1, January 2016, Pp.20-26.

[15] Kotler, P. Andreasen, A. (1991). Strategic marketing fornonprofi $t$ organizations. 4th ed. New Jersey: Prentice Hall.

[16] Kumar, A. (2014) Marketing of information products and services in Kurukshetra University library in the discipline of social science: A study.IOSR Journal of humanities and social science, 1(2), 72-85.

[17] Lovelock, C. H., Wirtz, J., Keh, H. T., \& Lu, X. (2002). Services marketing in Asia: managing people, technology, and strategy. Singapore: Prentice Hall.

[18] Lovelock, C. (2011). Services Marketing, 7/e. Pearson Education India. 


\section{International Journal of Science and Research (IJSR) \\ ISSN (Online): 2319-7064 \\ Index Copernicus Value (2016): 79.57 | Impact Factor (2015): 6.391}

[19] Madhusudhan, M. (2008) "Marketing of library and information services and products inuniversity libraries: A case study of GOA University Library". Library Philosophy andPractice: 1-6. Available at http://unllib.unl.edu/LPP/madhusudhan.pdf (Accessed 12 December, 2016).

[20] Min, Y., \&Jeong, D. Y. (2016).A Study on the Evaluation of Service Quality and ImportancePerformance Analysis in Research Libraries. Journal of the Korean Society for Library and Information Science, 50(1), 209-233.

[21] Mohindra, R., \& Kumar, A. (2015). User Satisfaction Regarding Quality of Library Services of AC Joshi Library, Panjab University, Chandigarh. DESIDOC Journal of Library \& Information Technology, 35(1).

[22] Moses, C. L., Olaleke, O., Oluwafunmilayo, A. M., \&Gbenga, A. M. (2016).Perceived Service Quality and User Satisfaction in Library Environment. Asian Journal of Information Technology, 15(1), 18-25.

[23] Nwoha, C. M. (2016).Users'perception of the facilities, resources and services of the mtn digital library at the university of nigeria, nsukka. Library Philosophy and Practice, 1.

[24] Oluwunmi, A. O., Durodola, O. D., \&Ajayi, C. A. (2016). Students' Perceived Quality of Library Facilities and Services in Nigerian Private Universities.Journal of Education and Training Studies, 4(5), 41-50.

[25]Rehman, S. U. (2016). Measuring service quality in public and private sector university libraries of Pakistan. Pakistan Journal of Information Management \& Libraries (PJIM\&L), 13.

[26] Seth, N., Deshmukh, S. G., \&Vrat, P. (2005). Service quality models: a review. International journal of quality \& reliability management, 22(9), 913-949.

[27] Singh, G., \& Kumar, M. (2016).Analyzing Students' Perception and Attitude towards Service Quality Delivery in Higher Educational Institutions of Punjab. Global Business and Management Research, 8(1), 18.

[28] Teeroovengadum, V., Kamalanabhan, T. J., \&Seebaluck, A. K. (2016).Measuring service quality in higher education: Development of a hierarchical model (HESQUAL). Quality Assurance in Education, 24(2), 244-258.

[29] Parasuraman, A., Berry, L. L., \&Zeithaml, V. A. (1991). Perceived service quality as a customer-based performance measure: An empirical examination of organizational barriers using an extended service quality model. Human Resource Management, 30(3), 335-364.

[30] Vasileiou, M. and Rowley, J. (2011)."Marketing and promotion of e-books in academiclibraries".Journal of Documentation, Vol. 67, No.4, pp. 624-643. Available at

http://www.emeraldinsight.com/journals.htm?issn=0022 - 418\&volume $=67 \&$ issue $=4 \&$ articlei (Accessed 01 February, 2017)

[31] Velnamby, T., \&Sivesan, S. (2013).Factor analysis of service quality in University Libraries in Sri Lanka-an application of Servqual Model.

Volume 6 Issue 12, December 2017

www.ijsr.net

Licensed Under Creative Commons Attribution CC BY 